\title{
Association of mitochondrial lysyl-tRNA synthetase with HIV-1 GagPol involves catalytic domain of the synthetase and transframe and integrase domains of Pol
}

\author{
L. Kobbi', J. Dias', G. Octobre', M. Comisso', M. Kaminska ${ }^{1}$, V. F. Shalak ${ }^{1,2}$, M. Mirande \\ ${ }^{1} \mathrm{CNRS}$ \\ 1, Ave. de la Terrasse, Gif-sur-Yvette, France, 91190 \\ ${ }^{2}$ Institute of Molecular Biology and Genetics, NAS of Ukraine \\ 150, Akademika Zabolotnoho Str., Kyiv, Ukraine, 03680 \\ mirande@1ebs.cnrs-gif.fr
}

\begin{abstract}
Aim. Analyze the interaction between Lysyl-tRNA synthetase (LysRS) and HIV-1 GagPol to know whether a particular N-terminal sequence of mitochondrial LysRS triggers a specific recognition with GagPol. Methods. Yeast two-hybrid analysis, immunoprecipitation. Results. We have shown that LysRS associates with the Pol domain of GagPol. Conclusions. A model of the assembly of the LysRS:tRNA ${ }_{3}^{\text {Lys }}$ :GagPol packaging complex is proposed.

Keywords: $t R N A_{3}^{\text {Lys }}$, lysyl-tRNA synthetase, HIV-1, packaging.
\end{abstract}

Lysyl-tRNA synthetase (LysRS) is an essential protein involved in translation of genetic information in the cytosol, where it is a component of a supramolecular complex [1], but also in mitochondria of human cells. Beyond its role in translation, this enzyme is also involved in various pathologies. Cytosolic human LysRS triggers proinflammatory response, and serves as a key signaling molecule in the immune response $[2,3]$. The mitochondrial species of LysRS interacts with a mutant of $\mathrm{Cu}, \mathrm{Zn}$-superoxide dismutase (SOD1) and contributes to mitochondrial dysfunction in amyotrophic lateral sclerosis (ALS) [4]. This enzyme is also hijacked from the host cell following HIV-1 infection to carry the primer tRNA ${ }_{3}^{\text {Lys }}$ into the virions [5]. The regulation of the spatio-temporal organization of this enzyme is a key element to understand the regulation of its activities.

Cytosolic and mitochondrial LysRS are encoded by a single gene [6] and can only be distinguished accor-

(C) Institute of Molecular Biology and Genetics, NAS of Ukraine, 2011 ding to their very $\mathrm{N}$-terminal sequences [5]. It was previously believed that cytosolic LysRS is packaged into HIV-1 virions via its association with Gag [7]. Using monospecific antibodies, it was later shown that only the mitochondrial LysRS is taken up in viral particles along with $\mathrm{tRNA}_{3}^{\text {Lys }}$, the primer for reverse transcription of the HIV-1 genome [5]. We re-analyzed the interaction between LysRS and GagPol to know whether the particular N-terminal sequence of mitochondrial LysRS triggers a specific recognition with GagPol, or if differential routing of the two LysRS species in vivo could explain specific and exclusive packaging of the mitochondrial species. We showed that LysRS associates with the Pol domain of GagPol. More specifically, the transframe (TF or $6^{*}$ ) and integrase (IN) domain proteins of Pol interact with the catalytic domain of LysRS [8]. A model of the assembly of the LysRS: tRNA $_{3}^{\text {Lys }}$ :GagPol packaging complex is proposed, which is also consistent with the release of its different components after maturation of GagPol in the virions 
(Figure, see inset). The cytoplasmic and mitochondrial LysRS species share an identical catalytic domain. Accordingly, we found that both enzymes have the intrinsic capacity to bind to GagPol in vitro. In addition, both enzymes interact with $\mathrm{p} 38$ in vitro, the scaffold protein of the cytoplasmic multi-aminoacyl-tRNA synthetase complex, even though only the cytoplasmic species of LysRS is a bona fide component of this complex. These results suggest that the different LysRS species are strictly targeted in vivo. Maturation of the premitochondrial form of LysRS upon its mitochondrial targeting is a prerequisite for its catalytic activation. These data open new perspectives for the search of a new class of inhibitors of the HIV-1 development cycle that would block the packaging of $\mathrm{tRNA}_{3}^{\text {Lys }}$ into viral particles.

Л. Кобі, Дж. Діас, П. Октобр, М. Комісо, М. Камінська, В. Ф. Шалак, М. Міранд

Асоціація мітохондріальної лізил-тРНК синтетази 3 білком GagPol ВІЛ-1 відбувається через каталітичний домен синтетази і трансматричний та інтегразний домени білка Pol

\section{Резюме}

Мета. Встановити, чи може $N$-кінцева послідовність, яка є специфічною для мітохондріальної форми лізил-тРНК синтетази, забезпечувати взаємодію иьього ферменту з білком GagPol BIЛ-1. Методи. Двогібридна дріжджсва система, імунопрецииітаиія. Результати. Ми показали що лізил-тРНК синтетаза взаємодіє 3 доменом Pol білка Gag. Висновки. Запропоновано модель утворення комплексу ЛізРC:mPHK ${ }_{3}^{\text {Лiз }}$ :GagPol.

Ключові слова: $\mathrm{PPHК}_{3}^{\text {Ліз }}$, лізил-тРНК синтетаза, ВІЛ-1, збирання віріона.

Л. Коби, Дж. Диас, П. Октобр, М. Комисо, М. Каминская, В. Ф. Шалак, М. Миранд

Ассоциация митохондриальной лизил-тРНК синтетазы с белком GagPol ВИЧ-1 происходит посредством каталитического домена синтатазы и трансматричный и интергазный домены белка Pol

Резюме

Цель. Выяснить, может ли N-концевая последовательность, являющаяся специфичной для митохондриальной формы лизил-
тРНК синтетазы, обеспечивать взаимодействие этого фермента с белком GagPol ВИЧ-1. Методы. Двугибридная дрожжевая система, иммунопреципитация Результаты. Мы показали, что лизил-тРНК синтетаза взаимодействует с доменом Pоl белка Gag. Выводы. Предложена модель образования комплекса ЛизРС: $\mathrm{mPHK}_{3}^{\text {Лus }}$ : GagPol.

Ключевые слова: РНКК $_{3}^{\text {Лиз }}$, лизил-тРНК синтетаза, ВИЧ-1, сбрка вириона.

\section{REFERENCES}

1. Kaminska M., Havrylenko S., Decottignies P., Gillet S., Le Marechal P., Negrutskii B., Mirande M. Dissection of the structural organization of the aminoacyl-tRNA synthetase complex // J. Biol. Chem.-2009.-284, N 10.-P. 6053-6060.

2. Park S. G., Kim H. J., Min Y. H., Choi E. C., Shin Y. K., Park B. J., Lee $S$. W., Kim $S$. Human lysyl-tRNA synthetase is secreted to trigger proinflammatory response // Proc. Natl Acad. Sci. USA.-2005.-102, N 18.-P. 6356-6361.

3. Yannay-Cohen N., Carmi-Levy I., Kay G., Yang C. M., Han J. M., Kemeny D. M., Kim S., Nechushtan H., Razin E. LysRS serves as a key signaling molecule in the immune response by regulating gene expression // Mol. Cell.-2009.-34, N 5.-P. 603611.

4. Kawamata H., Magrane J., Kunst C., King M. P., Manfredi G. Lysyl-tRNA synthetase is a target for mutant SOD1 toxicity in mitochondria // J. Biol. Chem.-2008.-283, N 42.-P. 2832128328.

5. Kaminska M., Shalak V., Francin M., Mirande M. Viral hijacking of mitochondrial lysyl-tRNA synthetase // J. Virol.-2007.81, N 1.-P. 68-73.

6. Tolkunova E., Park H., Xia J., King M. P., Davidson E. The human lysyl-tRNA synthetase gene encodes both the cytoplasmic and mitochondrial enzymes by means of an unusual alternative splicing of the primary transcript // J. Biol. Chem.-2000.-275, N 45.-P. 35063-35069.

7. Javanbakht H., Halwani R., Cen S., Saadatmand J., MusierForsyth K., Gottlinger H., Kleiman L. The interaction between HIV-1 Gag and human lysyl-tRNA synthetase during viral assembly // J. Biol. Chem.-2003.-278, N 30.-P. 27644-27651.

8. Kobbi L., Octobre G., Dias J., Comisso M., Mirande M. Association of mitochondrial Lysyl-tRNA synthetase with HIV-1 Gag Pol involves catalytic domain of the synthetase and transframe and integrase domains of Pol // J. Mol. Biol.-2011.-410, N 5.P. 875-886.
UDC 577.22

Received 20.06.11 
Figures to article by P. O. Areshkov et al.

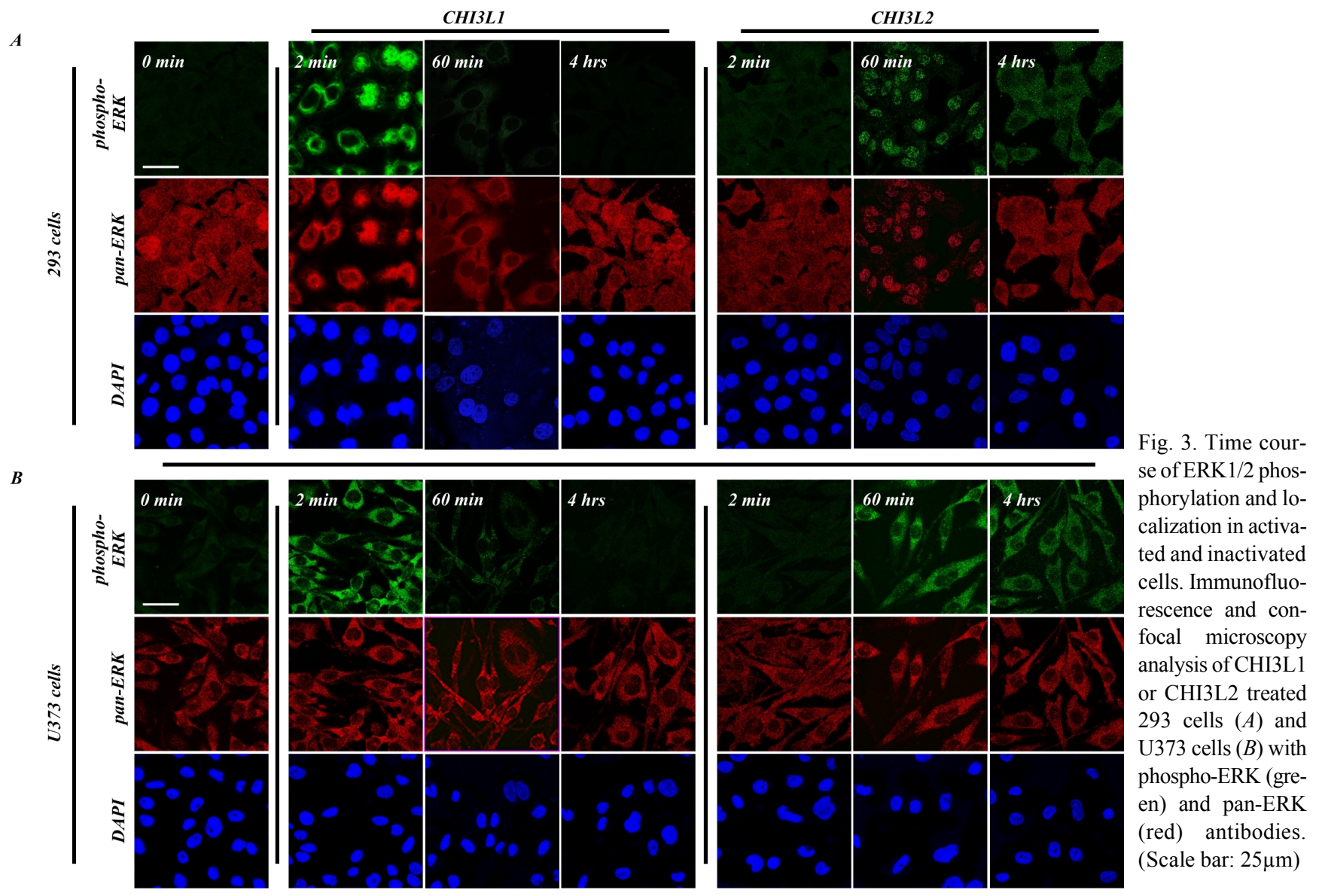

Figure to article by L. Kobbi et al.

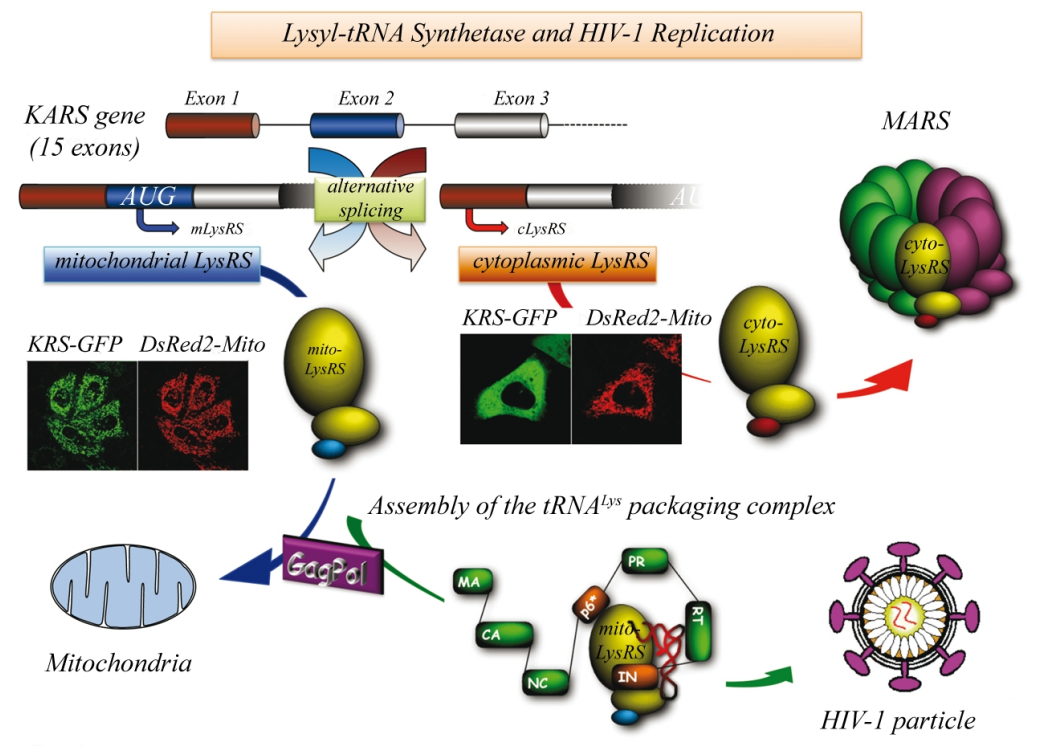

In human, a single gene encodes the cytoplasmic and mitochondrial forms of lysyl-tRNA synthetase by means of alternative splicing. The cytoplasmic isoform is produced from the mRNA lacking exon 2. This isoform is targeted to the MARS (Multi Aminoacyl-tRNA Synthetase) complex. The mitochondrial species is produced by translation initiation at the level of exon 2. Mitochondrial LysRS is specifically hijacked by the GagPol precursor protein during the process of packaging of HIV-1 particles. Association of mLysRS with GagPol involves catalytic domain of the synthetase and transframe (p6*) and integrase domains of the Pol region of GagPol. The formation of the tRNA(Lys, 3) packaging complex is an essential process of the HIV-1 life cycle, since this tRNA is required for initiation of reverse transcription of the RNA genome of HIV-1. The tRNA(Lys, 3) packaging complex is a potential therapeutic target 